IHiS (Indonesian Historical Studies) 4 (2), 84-99 (C) 2020 | E-ISSN: 2579-4213

\title{
Colonial Anxiety and Identity: Ethnic Networks as Cultural Supports in Colonial South Asia and Sumatra
}

\author{
Edward Owen Teggin \\ Trinity College, Dublin, Ireland \\ *Corresponding Author: teggine@gmail.com \\ DOI: https://doi.org/10.14710/ihis.v4i2.8891
}

\begin{abstract}
This study was inspired by research into the personal correspondence of colonial servants in Sumatra and South Asia, and the realisation that their articulation of negative emotions such as anxiety or fear are ill-fitted to the current wider understanding of colonial anxiety. This article argues that the progress of colonial empires was widely shaped by negative emotions such as these, yet there were

Received:

September 7, 2020

Revised:

December 2, 2020

Accepted:

December 1, 2020 also methods used by colonial servants to deal with such negative experiences. The core example of this has been the case studies of Robert Cowan and Alexander Hall; these men's letter archives display their usage of correspondence networks as part of their coping strategy. It is argued that these specifically ethnic, and at times gendered, correspondence networks formed a cultural bulwark which was used to cope with aspects of colonial anxiety. The method of this study therefore was epistolary examination to gather evidence and construct arguments. The archives of Cowan and Hall were compared and examined side by side to identify common patters and content. These were then considered in tandem with the current wider understanding of colonial anxiety. Based on the evidence gathered, it has been concluded that ethnic networks such as those examined could mitigate aspects of colonial anxiety. At the same time, these also demonstrate the great potential for future interdisciplinary studies involving personal histories tied to both Sumatra and South Asia.
\end{abstract}

Keywords: Colonial Empire; Anxiety; Correspondence Networks; Robert Cowan; Alexander Hall.

\section{Introduction}

In recent years, studies into the role of ethnic networks in empire have been a popular method of examining the colonial experience of diverse others from within the British Isles, especially for the eighteenth and nineteenth centuries. Indeed, Crosbie (2011) and Walsh (2010) have written extensively on the role of Irish ethnic networks operating both at home and in empire for this period, with Walsh particularly highlighting the activities of Ulster-Scots Presbyterian interests. MacKillop (2006), meanwhile, has discussed the role of Scottish Company servants and adventurers to India during the long eighteenth century. Recent research into the career of Sir Robert Cowan, governor of Bombay (1729-1734), has also expanded upon the existing knowledge base of early eighteenth-century ethnic Irish participation in empire. Of particular interest in this 
regard has been his involvement in early-modern East India Company activity in the Western Indian Ocean. This has provided the means for a variety of axial studies based on his large extant personal correspondence archive Teggin (2020). Through such an examination of personal experience in empire as a case study of the "New Imperial History" which has come to represent imperialism as a process of cultural transformation, it is argued that new avenues into imperial history, particularly through the idea of ethically-driven networks, may be opened through the partnership of epistological historical studies and cultural investigation.

Whilst the surrounding scholarship has effectively discussed the many benefits which members of an ethnic network could derive from their association with a structured ethnic apparatus, both at home and overseas, the debate surrounding its role as a form of bulwark against negative colonial experiences has been relatively neglected. In particular, this paper seeks to address the challenge of colonial anxiety upon colonial servants in empire and how, through an established ethnic cultural network, some of these difficulties could be overcome or mitigated. In particular, this study argues that the history of colonial empires has largely been shaped by personal experiences of negative emotions such as anxiety, fear, embarrassment and panic. This also serves to demonstrate that colonial anxiety, much like the stem anxiety, is not a singular indivisible whole and can manifest in different ways. Filor (2018) has done some excellent research into the life of Alexander Hall, factor at Sumatra (1751-1764), with a particular attention to his Scottish ethnicity and how it was a mainstay of his experience in empire. Cowan will be the core example investigated; however, the case of Hall will also be discussed to provide a comparative case study. Whilst the factors of location and time were vastly different for Cowan and Hall, with Cowan having served in Bombay, Goa, Mocha and Surat whilst Hall was confined to Sumatra, this is also an interesting opportunity to examine how ethnicity and shared culture played a role in alleviating colonial anxiety under varied circumstances. It will be argued that ethnicity, as well as association with an effective globally-linked network, played a key role in the personal experiences of individuals such as Cowan and Hall. As such, the use of these networks as cultural supports, and thus a link to the familiar, will be a central focus.

In terms of the established historiography on colonial anxiety, Ranajit Guha's famous 1997 article 'Not at Home in Empire' has been the starting point for many debates on the subject. Guha (1997, p. 483) posited that since the empire needed no homes, with the form and function of habitation having been satisfied by forts and garrisons, colonial servants felt a specific inability to make themselves at home in imperial territories. This encapsulated both the physical creation of a personal home, as well as the vast cultural difference between coloniser and colonised. This failure of habitation was, according to Guha, due to the forced imposition of new societal and cultural norms on the native population by a powerful alien force. Whilst Guha's discussion was certainly focused on the Company Raj period when British control of India was on a much firmer footing, his arguments and factors identified are still very much relevant to the cases of Cowan and Hall. Despite the supposed one-way power 
structure, Guha drew special attention to the unease which colonial officials often felt due to the vastness of India beyond them and the great cultural differences between them and the indigenous population. Guha's quoting of the British Officer, Francis Yeats-Brown, from the Lives of a Bengal Lancer (1930) was a fine case in point of this:

"I had sometimes a sense of isolation, of being a caged white monkey in a zoo whose patrons were this incredibly numerous beige race. Riding through the densely packed bazaars of Bareilly city...passing village temples, cantering across the magical plains that stretched away to the Himalayas, I shivered at the millions and immensities and secrecies of India. I liked to finish my day at the club, in a world whose limits were known and where people answered my beck. An incandescent lamp coughed its light over shrivelled glass and dusty shrubbery; in its circle of illumination exiled heads were bent over English newspapers, their thoughts far away, but close to mine. Outside, people prayed and plotted and mated and died on a scale unimaginable and uncomfortable. We English were a caste. White overlords or white monkeys, it was all the same. The Brahmins made a circle within which they cooked their food. So did we. We were a caste: pariahs to them, princes in our own estimation" (1997, p. 483).

Yeats-Brown's use of the expression "in a world whose limits were known" was highly suggestive of the feeling of comfort and security within his artificial surroundings of the gentleman's club, and fearful of the world without due to his lack of understanding of it. Essentially, this drew cultural considerations firmly towards those of ethnicity as a means of coping with the colonial encounter and understanding the individual's place in empire. Whilst the gentleman's club, officers' mess or hill station provided cultural stability for colonial servants suffering from colonial anxiety, they did not necessarily guarantee that an individual may have found ethnic connections there. Diverse ethnic others from within the British Isles all contributed to the imperial project, thus providing the potential for atomised cultural associations within seemingly aligned racial or ethnic settings. Indeed, Yeats-Brown's example of the many colonial servants hunched over newspapers in silence suggested that whilst there might have been numerous fellow servants surrounding the individual, colonial service also had the potential to be a very isolating and lonely experience. Colonial anxiety, in its broad understanding, has mostly been concerned with the idea of a fear of the unknown or foreign, and what Axel has said was the identification of a certain fragility of station which colonial servants possessed (2002, p. 17-21). This, combined with the idea of fear brought on by the prospect of attack, has left the wider discussion of colonial anxiety rather one-dimensional. However, by incorporating new approaches such as the identification of ethnic colonial networks in spaces of colonial action such as Sumatra and South Asia, it is argued that the definition of colonial anxiety may be brought more fully into the global debate.

\section{Historical Analysis of the Irish Network in Sumatra and South Asia}

The discussion of loneliness amongst colonial servants is a fitting place to begin the description of Robert Cowan's colonial experience due to the great amount of his personal correspondence which draws attention to his feelings. Whilst Cowan served 
the company in the western presidency between 1721-1734, and was noted to have been very successful in both personal and professional terms, he did experience two distinct period of his career when he suffered from loneliness, anxiety and despondency. These were his postings at Goa (1721-1722) and Mocha (1724-1727). Like many colonial servants, Cowan embarked on his Indian career with the specific intention of making a great personal fortune through private trade. However, during his early years of service he was greatly restricted in his ability to trade privately due to a lack of capital and poor market conditions (Cowan, 1724a: 15v). These factors certainly presented themselves as a cause for concern in his correspondence, although they were by no means the only issues at play. In his first placement at Goa, Cowan bemoaned the fact that he had only spoken Portuguese for eight months. This was compounded by a lack of fellow servants for company, with him only having had a native maid and manservant living with him: "I have never wanted company more than now.. at least $i$ have peace and quiet in my little family" (Cowan, 1721c: 69v). This was similar to the issue raised by Guha in the case of Yeats-Brown, with Cowan seemingly having experienced a cultural disconnect with the world around him. Whilst Goa was a Portuguese colony and governed along European lines, Cowan was newly arrived in India and was at once despatched to a station which was ethnically and culturally alien to him.

Cowan had been despatched to Goa in february 1721 to act as the company representative there, as well as to negotiate an alliance with the Portuguese against the Maratha admiral Kanhoji Angré. Angré had carried out raids on European shipping along the west coast of India for many years, and was generally considered by European nations to have been a pirate (Cowan, 1721a: 4v). However, this was an oversimplified and biased label to use for a man who had served as deputy commander of the Maratha navy since 1690. During Cowan's time at Goa and his negotiations with the Portuguese authorities, it appears that he developed a great dislike of the "haughty" Portuguese of Goa. He did not, however, specify whether this applied to ethnic Portuguese from Europe, Portuguese born as a result of intermarriage, or a combination of both. Indeed, the only Portuguese individual he developed any respect for was Francisco José de Sampaio é Castro, the viceroy of Portuguese India (1720-1723) (Cowan, 1721b: 18v). This suggested that Cowan felt a disconnect from both indigenous populations, as well as culturally diverse others of European ethnicity also. The exemption of the viceroy was intriguing, but this was likely linked more so to his status as a head of government rather than any ethnic or cultural consideration.

Whilst the negotiations ultimately led to the successful conclusion of a treaty between the two powers, the expedition itself was an outright failure. The joint expedition took place between october and november 1721 with the stated aim of capturing Angré's island fortress of Kolaba, south of Bombay. Upon arrival at Kolaba, the first assault was easily repulsed and the Portuguese viceroy, the overall expedition commander, fell ill during the night. According to Cowan, this led the Portuguese contingent to shrink and make a separate peace with the Marathas and retreat; this, 
Cowan described as "scandalous". Indeed, in his reports on the failed expedition, Cowan levelled all the blame at the Portuguese cowardice and bemoaned the failure of two European powers to defeat a so-called native pirate (Cowan, 1722b: 106v; 1722a: $188 \mathrm{v})$. From this episode it can be suggested that Cowan's distaste and cultural disconnect from his surroundings at Goa had two specific dimensions. First, that he felt alone and caged, along the lines of Guha's assessment of Yeats-Brown. This saw him develop a melancholy surrounding his life at Goa. Second, that the alleged failures of the Portuguese, in terms of their "haughty" attitude and lack of courage further distanced him from the surrounding populace. Effectively, he had become culturally isolated in both geographical and interpersonal terms.

The cultural disconnection was also true for Cowan during his tenure as chief of the Mocha factory. However, instead of serving at a European overseas colony, his time at Mocha saw him being based in the independent Zaidi-Muslim Imamate of Yemen. This brought with it new cultural and interpersonal difficulties due to the extreme lack of familiarity and conservative Islamic society in which he found himself. Here, the disconnect suggested by Guha was once again relevant due to the additional vastness of the Middle-Eastern sphere having been added to that of the South Asian expanse which he initially encountered. Once again, Cowan experienced loneliness as a result of his placement which was also combined with aches and pains. Viewing a negative emotional experience in conjunction with the social isolation and phantom pains which Cowan suffered from at this time with hindsight might lead to a suggestion of depression or generalised anxiety disorder in him. However, this would be an imperfect retrospective diagnosis and so it must remain as a supposition. Despite this, what can be gleaned is that Cowan felt the need to retreat to Bombay during the slow trading season at Mocha (September to January) every year during his Mochan employment as a result of fatigue and associated medical complaints (Cowan, 1724d: 28). This might be viewed as an attempt to depart the uncertainty and unfamiliarity of Mocha, and escape to the more culturally attuned settlement of Bombay where a far greater number of Europeans were based. This again returns to Guha and his assumptions regarding the known and unknown, with Cowan clearly having sought to escape from the "cage" of being surrounded by ethnically and racially diverse others.

Cowan's loneliness and persistent illnesses were not the only way in which his colonial anxiety at Mocha expressed itself, however. Indeed, Cowan developed a very negative attitude towards the indigenous population across his time there. The allegation that natives were often lazy was a commonly-expressed form of Europeans asserting their alleged racial dominance over indigenous populations in the early colonial period, and so such descriptions can be discarded as stemming from the European feeling anxious about his own position and thus feeling the need to differentiate himself. The basis of Cowan's allegations was his belief that the natives were "insolent" or "rascally", and his evidence that there was a high degree of what he viewed as despotic governance at Mocha during these years (Cowan, 1725b: 111$111 v)$. In particular, it was alleged that both the ruling Imam and a Mochan merchant 
named Cosim Turbatty had conspired to manipulate the market mechanisms to their own advantage. This included limiting market access to outsiders, withholding produce, and the non-payment of debts. The most pressing element of this for Cowan and the Company, however, was Turbatty's interference in the coffee trade; coffee, as the most important commodity sourced at Mocha, was an important luxury product for the Company. However, as a result of Turbatty's machinations, Cowan alleged that the price of coffee had increased from 80 Spanish dollars a bale to 200 dollars between 1724-1725. This was in addition to Turbatty's alleged use of intimidation and violence to prevent other Mochan merchants purchasing European goods such as tin in the Mochan marketplace. Essentially, this served to keep prices artificially low for his own benefit (Cowan, 1725a: 55v-56).

Cowan also expressed his deep concern that the ruling Imam and Turbatty were using the Company as a scapegoat for the wider economic depression in Yemen caused by famine and civil war (Cowan, 1725a: 55v-56). For Cowan, this appeared as further evidence for the despotic nature of the Mochan government, and thus a reminder of his own cultural disconnection from the people and place. Whilst it was entirely possible that such dealings had occurred, Cowan's negative review of the populace in tandem with his accusations of despotism are familiar in the wider understanding of the colonial experience. Jon Wilson has highlighted that accusations of despotism were regularly used by colonial servants and orientalists as a means of articulating the distance individuals felt between their own western cultural identity and native society (Wilson, 2010, p. 65). This is also reminiscent of the arguments of Syed Hussein Alatas in his famous work, The Myth of the Lazy Native (1977). Cowan's view of Mocha as a victim of despotic government also went hand in hand with his negative review of both the local climate and market mechanisms to complete the vision of a servant suffering from colonial anxiety:

It has been my fate to ramble much since my being in India \& i can't look upon myself as yet settled as little do i desire it in this wretched place which is much worse than it was discribed [sic.] to me in every respect. Cesars [sic.] maxim prevailed with me he chose to be Chief of a Village rather than Second in Rome and I was ambitious of being a Chief as soon as i could, not so much for the honour as the profit [sic.] but this i find is no ways equal to what $\mathrm{i}$ was made to believe nor indeed the fatigue we undergo by living here[...] (Cowan, 1724b: 1-1v).

Whilst colonial servants such as Cowan might reasonably have expected privations, personal discomforts or cultural disconnects as a result of their service, Cowan clearly felt that Mocha was below even an acceptable level of hardship. However, Mocha had been Cowan's own choice and he had made the decision with the intention of making a great deal of money. Much in the same way, Alexander Hall also had a personal preference for where he wished to serve the Company later in the eighteenth century. Hall's posting of choice was Calcutta, the capital of the Bengal presidency following the construction of Fort William (1696-1702) and the centre of company administration in India from 1773 onwards, where he believed he would make considerable profits. Hall, however, was posted to Sumatra and remained in the 
factory's service throughout his career, despite numerous petitions to senior company figures for a transfer. Profit then was a key element in a colonial servant's desire to serve in specific factories, and indeed to effectively settle in them. Cowan had primarily complained of the climate and lack of trading opportunities, with Mocha in the 1720s seemingly being in a poor economic state. In a similar way, Hall (1756) had complained of the poor financial outlook for himself if he remained at Sumatra.

Whilst the common emotions and difficulties experienced by both Cowan and Hall were interesting in their own right, what was more intriguing was the manner in which they chose to broadcast their thoughts. Both men used their private correspondence to family or close friends to express themselves. Networked correspondence, according to David Hancock (2007, p. 8-10), was used to convey the idea of an interconnected group of people exchanging information, goods and services between specifically networked nodes. Whilst the use of early-modern epistolary sources as a means of investigating the experience of colonial servants is an established element of historical examination, there is a relative lack of personal archive material, particularly for more private matters in the early colonial period, as argued by Søren Mentz (2005, p. 81). This is a particular reason why the Cowan archive, and to a lesser extent Hall's papers, have the potential to enable fresh perspectives on the colonial experience. Familial networks, as such, have been a fascinating recent development in the study of networks in empire, with the debate begun by Margot Finn (2011) on the familial proto-state forming a key plank of this. However, central to the current investigation is how the networks of correspondence used by the likes of Cowan and Hall were employed as a means of achieving cultural familiarity with fellow countrymen and kin-networks. It is argued that these ethnically-driven cultural networks formed the basis of a coping mechanism for colonial servants suffering from what has come to be known as colonial anxiety within postcolonial circles.

Cowan, as noted above, wrote specifically of his distaste for indigenous peoples, climate and his own isolation as a method of dealing with his colonial anxiety. However, it was less the content of these letters which are of interest here, and more so to whom they were directed. It has been argued elsewhere that Cowan had specific spikes in his correspondence when he was stationed at Goa and Mocha as a direct result of his colonial anxiety. This manifested itself as a distinct element of gendered correspondence whereby he engaged in writing letters to female friends and family members to express himself and derive emotional support. As can be seen in Table 1 of the 287 letters he wrote during his time at Goa, 16 were to his gendered support network. Similarly, for his time at Mocha, Cowan wrote 18 letters out of 558 to female correspondents (Teggin 2020, p. 52-54). Whilst these figures were fractions of the total number of letters sent, they were significant when it is considered that Cowan doesn't appear to have accessed his gendered correspondence network again during his time in India. These two spikes at Goa and Mocha were then very important in understanding his need for familiar gendered connections at these times. However, it is argued that his use of a specific ethnic correspondence network running parallel at the same time was just as important. Indeed, whilst Cowan displayed spikes in his 
gendered correspondence during his Goan and Mochan placements, spikes in his ethnically-driven correspondence are also witnessed.

Table 1. Gendered and Ethnically-driven network correspondence for Robert Cowan. 1721-1722; 1724-1727.

\begin{tabular}{|c|c|c|c|}
\hline Correspondent(s) & $\begin{array}{c}\text { Letter } \\
\text { Origin(s) }\end{array}$ & $\begin{array}{l}\text { Number of Gendered } \\
\text { Network Letters }\end{array}$ & $\begin{array}{l}\text { Number of Ethnic } \\
\text { Network Letters }\end{array}$ \\
\hline Elizabeth Gould & Goa & 2 & 2 \\
\hline Henry Cairnes & Goa & & 7 \\
\hline Hugh Henry & Goa & & 2 \\
\hline John Cowan & Goa & & 4 \\
\hline John Gould & Goa & & 4 \\
\hline John Gould Jr. & Goa & & 1 \\
\hline Lady Cairnes & Goa & 7 & 7 \\
\hline Mrs. Macrae & Goa & 3 & \\
\hline Mrs. Davis & Goa & 2 & \\
\hline Mrs. Gould & Goa & 1 & 1 \\
\hline Robert Lennox & Goa & & 1 \\
\hline William Cowan & Goa & & 4 \\
\hline Mrs. Mullell & Goa & 1 & \\
\hline Total (Goa): 13 & & 16 & 33 \\
\hline Elizabeth Gould & Mocha & 6 & 6 \\
\hline Betty Shannon & Mocha & 1 & 1 \\
\hline John Cowan & Mocha & & 2 \\
\hline John Gould & Mocha & & 8 \\
\hline John Gould Jr. & Mocha & & 8 \\
\hline Mrs. Cairnes & Mocha & 2 & 2 \\
\hline Mrs. King & Mocha & 1 & \\
\hline Mrs. Macrae & Mocha & 4 & \\
\hline Mrs. Sterling & Mocha & 2 & \\
\hline Ms. Furness & Mocha & 2 & 2 \\
\hline Robert Lennox & Mocha & & 3 \\
\hline Robert Nesbitt & Mocha & & 2 \\
\hline William Cowan & Mocha & & 3 \\
\hline
\end{tabular}

Total (Mocha): 13

18

Source: Cowan, Robert. Letters. Cowan Papers. P.R.O.N.I., Belfast. D654/B/1/1AA \& D654/B/1/1C.

Further, what can be seen from table 1 , is that there are several general comments and assumptions which can immediately be made. First, that Cowan clearly had a degree of crossover when it came to his gendered and ethnic correspondence networks. Indeed, many of the women Cowan confided in were also a part of his familial or cultural network. Second, that the figures for Cowan's ethnically-driven network were also mere fractions of his total number of letters sent for the locations and periods in question. This was unsurprising given the large number of his letters which survive, as well as the multifaceted official role which he fulfilled for the East 
India Company. This naturally meant that there was a great amount of Company correspondence amongst Cowan's more private letters. Third, and perhaps most importantly, the number of ethnically-networked letters was approximately double that of the gendered correspondence for the same period. Whilst it was partially unsurprising that there would have been a greater number of letters for the ethnicallydriven network since it incorporated both men and women, it was also intriguing that Cowan sought comfort amongst male correspondents contained within his ethnic network. This was especially relevant given what Indrani Sen (2005, p. 26, 33) has described as mental illnesses, weakness or difficulty with regard to habitation having been viewed as a distinctly female complaint in the colonies during the early modern period. For Cowan to have expressed his difficulties or concerns to male correspondents there would likely have to have been a very firm and close relationship in place, otherwise it may have portrayed an unfavourable image regarding his masculinity and thus supposed suitability for his role.

\section{Cultural or Ethnically-Driven Correspondence Networks in Empire}

The solution to this problem is to be found in the notion of the cultural or ethnicallydriven network. The most prominent names displayed in table one, above, are those of Cairnes and Gould, with both families having held powerful financial and political connections in Ireland and the city of London in the early eighteenth century (Bailey, 2007, p. 163; Walsh, 2014, p.51-52). During his early career Cowan had succeeded in gaining entry into the Atlantic wine trade to Madeira with Henry Cairnes, a member of the prominent merchant and banking Cairnes family from Belfast (Fitter vs. Cairnes, 1718). The trade to Madeira for wine was an established venture in the wider ScotsPresbyterian commercial world, with Hancock's research into the trade having revealed extensive Scots, and to a lesser extent Irish, involvement in the early eighteenth century (Hancock, 2007, p. 9-10). It is argued that the increased involvement of trading interests from the British Isles during this period was also likely a result of the Methuen Treaty of 1703. This saw British customs on Portuguese wine reduced by a third, whilst the Portuguese removed tariffs on imported woollen goods. This served as a stimulus to both industries and provided an opportunity to culturally-driven networks such as that of the Cairnes family.

The initial Cairnes connection had come from William Cairnes' involvement with the Irish Parliament in Dublin, which involved him communicating with the Londonderry corporation council (Londonderry corporation, 1699, p. 174; 1700a, p. $178 ; 1700 b$, p. 184) which Cowan's father John sat on as both a burgess and alderman in the early eighteenth century. This was compounded by the prominent landowner and civil servant, William Conolly, being connected to the Cairnes family politically, and controlling the political scene in County Londonderry during John Cowan's tenure (Walsh, 2010, p. 110-111). Through Cowan's participation in the Cairnes' Atlantic trade, he then secured an introduction to the Gould family, in-laws of the Cairnes, based in London. The Goulds were heavily involved in Irish merchant banking and landed capital circles at the time as well, particularly with dissenting Irish 
interests between Belfast, Dublin and Londonderry (Bailey, 2007, p. 161, 163). The common theme which emerges when discussing Cowan's patronage and correspondence networks is that at the core was a strong and highly adaptable Presbyterian Irish community which served to support him personally and professionally throughout his career. Shared ethnicity, and thus cultural identity, was therefore a crucial factor in the construction and maintenance of Cowan's private correspondence. This was in line with David Hancock's (2007, p. 16-18) arguments on the nature of private networks, with the preferred method having been the granting of patronage and network patronage to those who held shared links of memory, ethnicity, home and family.

Cowan's betrothal to Elizabeth Gould prior to his departure to India was evidence of Hancock's theory at work. Indeed, as can be seen from table one, many of Cowan's cultural network correspondents were also members of his wider ethnicallydriven patronage network, as well as the ladies from the Cairnes and Gould families. This was an intriguing crossover which suggested that the politics of family were also tied up in the politics of imperial patronage in empire. This returns to Finn's work on the familial proto-state, with the crux of her argument being that kin-based financial mechanisms underpinned British and European colonial expansion in India. The imperial connotation carried through from her discussion of the key role which family solidarity played in enabling economic progress by providing a means for managing financial risk across distances. In this way, loyalty to kin networks had both symbolic and highly functional importance (Finn, 2011, p. 101-103). It was clear that Cowan's interpersonal network was largely dependent on both ethnic and gendered elements to provide him with the support he needed during his difficult times in India, but given the above points arising out of table one, it is fair to comment that the cultural or ethnic element had the ability to exert a far greater degree of influence on him than the gendered element alone. Indeed, the fact that his gendered network was largely encompassed in his wider ethnic suggests as much. However, it is argued that the seemingly rival aspects were in fact two interdependent halves of a single greater cultural network which Cowan used. Whilst the individuals apart from his CairnesGould familial unit also supported him, Cowan directed his most private discussions to his familial base, as the extract below suggests. Effectively, this tied aspects of the gendered and ethnically-driven network into a single intimate cultural circle. A letter to his fiancé Elizabeth Gould on 8 Jul. 1724, contained similar elements to his earlier letter to Ms. Furness, but placed far greater emphasis on the emotional distress of his predicament.

I wrote my little wife with more heartfullness [sic.] from Bombay than i can do from hence, thou' [sic.] I flattered myself with a prospect i though i had of getting a great deal of money \& returning speedily to England to lay that and myself at your feet, but $i$ find myself much mistaken and should i stay longer at Mocha all my money in India would not render me worthy your notice. I don't imagine from this that $i$ think you regard mony otherways [sic.] than as a necessary concomitant, but if ever i was possessed of any good quality, this cursed place will strip me of it. The country's a Desart [sic.], the air postiserous [sic.], and all inhabitants insolent \& perfidious. Tis with 
regret that $i$ am obliged to speak a little of their language because willingly $i$ would not learn anything from them [...] (Cowan, 1724c, p. 14).

Meanwhile, Ellen Filor's discussion of Alexander Hall saw her describe Hall as having benefitted from networks of Scottish East India Company patronage, and that he sought to construct a sense of 'Scottishness' in Sumatra through the goods he had sent from home. These goods included newspapers, tinned salmon and powdered eggs (Filor, 2018, p. 328). First, it is important to highlight that Hall attempted to create a sense of his Scottish home in South East Asia as a means of coping with the separation from his friends, family and locality. This was suggestive of a defined need for the familiar as a means of coping, and was likely a facet of what comes under the wider heading of colonial anxiety. Indeed, Hall's need for the familiar was not merely due to his relocation halfway around the world, and he did in fact describe many similar complaints to those of Cowan. The most pressing were his exasperation at having failed to make a personal fortune, as well as the alleged apathy and laziness of the indigenous population. This represented both a cultural disconnect, as well as a feeling of isolation similar to the one which Guha (1997, p. 483-485) commented upon for Yeats-Brown.

"The only objection I have to it, is the want of trade which is owing to the natives of the country who although they have all the advantages with regard to soil c. [sic] yet they are so very indolent as to neglect their own sustenance in a manner" (Hall, 1751).

Whilst this entry suggested a cultural disconnect, Hall's primary concern appeared to stem from his disappointment at the lack of trade. This one letter did not tell the whole story of Hall's existence at Sumatra, however. Whilst Indonesia and Malaysia played a key role in international trade in the long eighteenth century, with the straits of Malacca being strategically located between the Indian Ocean and South China Sea, there was also a lack of ergonomic thinking for servants based there despite its great exposure to outside influences. As the anthropologist Freek Colombijn (2003, p. 506) has argued, the forced cultivation of pepper in the region by Europeans raised tension with local populations and also provoked regional disputes between rival colonial powers such as the Dutch and English. Sumatra, necessarily established as a garrisoned factory in the region, was run along military lines during Hall's period. This meant that his personal space was likely confined to a barracks subject to the routines and regulations of military life. As such, his supposed private space was also a very public one which was shared with fellow colonial servants and soldiers. This is reminiscent of the extract of Yeats-Brown's memoir commented upon by Guha, with Hall having seemingly been confined to the Company factory in much the same way Yeats-Brown retreated to his club. Whilst the presence of fellow exiles behind walls gave safety in the physical sense, it could not provide security in the form of cultural familiarity. As such, this was certainly a facet of the colonial anxiety experienced by Hall.

The solution to Hall's predicament was very similar to that used by Cowan. Hall engaged himself in ethnically-driven, and indeed familial, correspondence across his 
years in Sumatra with varying regularity. The letters in question were primarily directed to his mother, sister and brothers, but also included a handful of fellow Scots. Hall lacked the sophisticated patronage network which was utilised by Cowan; similarly, his ethnically-driven correspondence lacked the powerful financial and political connections enjoyed by Cowan. However, his ethnic correspondence, though comprised of a much smaller circle, served a similar purpose to that of Cowan's personal letters to his ethnic correspondence circle. This was that it served as a conduit for his emotional concerns, and as such was a means of expressing his colonial anxiety. Leaving his above-mentioned commercial disappointments and distaste for indigenous populations aside, this also manifested itself as the strong desire for the familiar in the form of friends, locations and products. Hall's letters to his brother John on 17 Apr. 1762, when briefly back in London following his ransom as a prisoner of war, and 3 Sept. 1763, when he had requested delicacies such as salmon and powdered eggs from Scotland, demonstrated this:

Already I have drawn this comfort from my voyage, that, were it not for the pleasure of being with you \& the rest of my friends in Scotland, I would immediately transport myself again to India, for I am heartily tired of - even London (Hall, 1762).

My salmon from Cockburn of Berwick, turns out well tho' [sic.] it had not very fair play, for I told him to put it in double cases, but he did not fill up the interstice with salt pickle as I desired him, besides there were some of the cases which would not hold in some salt beef pickle I poured in, aboard ship during the voyage. I dare say he may sell many hundred kitts [sic.] if its done properly, pray send me out four $1 / 2$ kitts [sic.] every year. Let them also be sent to George Fairholme. The torwoodlee eggs would not keep cross the line, they did not stick much, but they were very much evaporated \& of a stinking straw taste (Hall, 1763).

Thoughts of friends, home and aspects of material culture such as ethnic goods were a clear indication that Hall was seeking out elements of the familiar to alleviate his suffering. This idea of the familiar is akin to notions of a cultural connection, or indeed disconnect, for colonial servants. The example of Yeats-Brown seeking the familiar surrounds of his gentleman's club resonates here. Striving for the culturally familiar networks and loci once again links to Guha's arguments surrounding colonial anxiety in the wider vision of colonial service. Guha's famous analysis, articulated below, made the argument for it being the case that colonial servants became overwhelmed by the immensity of the vast unknown of empire in terms of population, geography, politics, culture, linguistics, etc. In his view, servants who were tasked with governing in empire were faced with the impossible task of administering a construct which they did not fully understand. That is to say nothing of their own lack of cultural understanding for the indigenous populations outside of the artificially created British zones of offices, barracks and forts. Guha, concluding that colonial servants were often out of place and poorly adapted to their situations, argued that these servants thus became "lost" in empire. His use of Yeats-Brown's analogy regarding "white monkeys" was also particularly relevant here; so too his description of servants trapped in the difficult task of imperial governance, shown below. This ran 
counter to much twentieth-century historiography which portrayed the expansion of empire as a coherent and widely enthusiastic project.

Its politics of expansion and improvement, its ethics of courage, discipline, and sacrifice, its aesthetics of orientalism have all been assimilated to this mood by a whole range of rhetorical, analytical, and narratological devices, so that enthusiasm has come to be regarded as the very mentality of imperialism itself. The result has been to promote image of the empire as a sort of machine operated by a crew who know only how to decide but not to doubt, who know only action but no circumspection, and, in the event of a breakdown, only fear and no anxiety. However, the picture does not look nearly so neat when we step outside official discourse and meet individual members of that crew agonizing like Yeats-Brown over the immensity of things in a world whose limits are not known to them (Guha, 1997, p. 487-488).

\section{Conclusion}

It must be acknowledged that both Cowan and Hall were involved in colonial service prior to the mass proliferation of East India Company rule in India, and so were thus only partially represented by many of Guha's assumptions. Whilst they certainly suffered from aspects of colonial anxiety discussed by Guha, such as cultural disconnection, they also experienced difficulties which were perhaps more closely related to their comparatively early service in empire. In particular, the lack of established infrastructure in Company factories, even greater sparsity of fellow Europeans, and the lack of ethnic associations conducted along formal lines. This latter point is a curious one, however, in that whilst there was little formal adjudication of cultural association, there was in fact a high degree of informal networking being carried out both in the metropolis and in empire. Cowan's penetration of the CairnesGould Irish Presbyterian commercial network and his activity within it was a good example of this. Whilst it was highly unlikely that ethnically-driven networks such as these were created with the intention of providing individuals non-commercial support, individual network nodes such as Cowan and Hall using them as such is an interesting concept. Indeed, Hancock has commented that networks were often constructed with the intention of providing solutions, mostly business in nature, for its members engaged in overseas commerce. As such, it is not entirely implausible that cultural considerations may have come into the discussion.

The point must also be made that networks such as these had the ability to be highly mutable in their characteristics. This further follows Hancock's arguments about the flexible nature of networks. The lack of rigid hierarchies in ethnic or cultural networks such as these also meant that individual members were free to become more heavily involved in other members' private lives. This freedom of association often led to intermarriage between families to secure network ties, as was the case with Cowan and his betrothal to Elizabeth Gould. Whilst cultural or ethnic networks were a convenient way of managing shared interests in empire, particularly with reference to the familial proto-state, they were also constructed with a far deeper practicality in mind. The notion of shared cultural memory and identity proved invaluable in securing loyalties, building trust and preventing misunderstandings. These ties of 
shared cultural experience meant that there was an inherent emotional connection between network nodes in ethnically-driven networks such as those used by Cowan and Hall. This suggested that the use of an ethnic or cultural correspondence network to express feelings of colonial anxiety, particularly over a uniquely gendered network in the same context, was highly likely. However, the caveat must once again be given that this idea of the cultural network included all ethnically-linked genders, and so was always likely to see a higher usage ratio than a gendered network alone.

The usage of culturally-driven networks is, as highlighted above, also closely linked to the notion of what has come to be understood in the wider field as the "New Imperial history", whereby it has been demonstrated that ethnic others from the British Isles such as the Irish, Scots and Welsh, also interacted with the colonies in a variety of ways. Intriguingly, this also provided the means for ethnic others from within the British Isles to transcend social and political barriers in the early eighteenth century in order to gain access to the imperial sphere. What has been particularly interesting, however, is the way in which Crosbie has argued that the combined experiences of these diverse others within empire makes for a fascinating lens of comparison for imperial studies. These also have the potential to add increasing layers of complexity to established national historical narratives; Crosbie (2011, p. 5-7) gave the example of the Irish in empire, with Irish participation often having been downplayed to benefit domestic political arguments (Walsh, 2010, p. 110-115). The relative lack of historical investigation into the various ways which ethnic others from the British Isles interacted with empire is surprising, yet it also offers a niche for keen scholars; particularly those seeking to understand notions of national culture within early empire. Whilst Crosbie (2011) has highlighted the powerful Sulivan network from County Cork in this regard, Walsh has also drawn attention to the CairnesConolly nexus in Ulster.

The new understanding of Cowan's career and archive has also significantly opened up the possibility for studying his wider dissenting cultural and familial network in empire. This has also provided evidence for the highly mutable nature of ethnically-motivated networks in empire. Whilst this article has argued that analysing the way in which cultural networks could be used as mitigators of colonial anxiety in empire is but one facet of the great potential which the study culturally-driven networks can have, it is also argued that this can be the basis of further axial studies. These may be conducted along the lines of the above-mentioned "New Imperial history" to further advance the ongoing debate; or, more importantly, to promote interdisciplinary cooperation and research surrounding both the history and concept of empire.

\section{References}

Alatas, S. H. (1977). The myth of the lazy native. London: Routledge.

Axel, B. K. (2002). From the margins: Historical anthropology and its futures. Durham: Duke University Press. 
Bailey, C. (2005). Metropole and colony: Irish networks and patronage in the Eighteenth-Century empire. Immigrants $\mathcal{E}$ Minorities 23, no. 2-3 (July-November): 161-181. https://doi.org/10.1080/02619280500188062.

Bailey, C. (2007). The nesbitts of London and their networks. In D. Dickson, J. Parmentier \& J. Ohlmeyer (Eds.), Irish and Scottish Mercantile Networks in Europe and Overseas in the Seventeenth and Eighteenth Centuries (pp. 231-250). Gent: Academia Press.

Colombijn, F. (2003). The volatile state in Southeast Asia: Evidence from Sumatra, 1600-1800. Journal of Asian Studies 62, no. 2 (May): 497-529. https://doi.org/10.2307/3096247.

Cowan, R. (1721a). Cowan to John Courtney, Goa, 8 February. Letter. Cowan Papers. P.R.O.N.I., Belfast. D654/B/1/1AA: f. 4v.

Cowan, R. (1721b). Cowan to Mr. Browne, Goa, 4 April. Letter. Cowan Papers. P.R.O.N.I., Belfast. D654/B/1/1AA: f. 18v.

Cowan, R. (1721c). Cowan to Mrs. Cairnes, Goa, 27 August. Letter. Cowan Papers. P.R.O.N.I., Belfast. D654/B/1/1AA: f. 69v.

Cowan, R. (1722a). Cowan to Mr. Cairnes, Goa, 6 January. Letter. Cowan Papers. P.R.O.N.I., Belfast. D654/B/1/1AA: f. 188v.

Cowan, R. (1722b). Cowan to Mr. Dawson, Goa, 6 January. Letter. Cowan Papers. P.R.O.N.I., Belfast. D654/B/1/1AA: f. 106v.

Cowan, R. (1724a). Cowan to John Cowan, Mocha, 8 July. Letter. Cowan Papers. P.R.O.N.I., Belfast. D654/B/1/1C: f. 15v.

Cowan, R. (1724b). Cowan to Ms. Furness, Mocha, 8 July. Letter. Cowan Papers. P.R.O.N.I., Belfast. D654/B/1/1C: ff. 1-1v.

Cowan, R. (1724c). Cowan to Elizabeth Gould, Mocha, 8 July. Letter. Cowan Papers. P.R.O.N.I., Belfast. D654/B/1/1C: f. 14.

Cowan, R. (1724d). Cowan to John Courtney, Bombay, 8 September. Letter. Cowan Papers. P.R.O.N.I., Belfast. D654/B/1/1C: f. 28.

Cowan, R. (1725a). Cowan to William Phipps, Mocha, 10 March. Letter. Cowan Papers. P.R.O.N.I., Belfast. D654/B/1/1C: ff. 55v-56.

Cowan, R. (1725b). Cowan to Thomas Woolley, Mocha, 1 August. Letter. Cowan Papers. P.R.O.N.I., Belfast. D654/B/1/1C: ff. 111-111v.

Crosbie, B. (2009). Ireland, colonial science, and the geographical construction of British rule in India, c. 1820-1870. Historical Journal 52, no. 4 (December): 963-987. https://doi.org/10.2307/25643866.

Crosbie, B. (2011). Irish Imperial Networks: Migration, Social Communication and Exchange in Nineteenth Century India. Cambridge: Cambridge University Press.

Filor, E. (2018). The intimate trade of Alexander Hall: Salmon and slaves in Scotland and Sumatra, c. 1745-1765. In M. Finn \& K. Smith (Eds.), The East India Company at home, 1757-1857 (pp. 318-332). London: UCL Press.

Finn, M. C. (2011). Family formations: Anglo India and the familial proto-state. In D. Feldman \& J. Lawrence (Eds.), Structures and transformations in modern British history (pp. 100-117). Cambridge: Cambridge University Press. 
Fitter vs. Cairnes, Bill and Answer. (1718). National Archives, Kew. C/11/2614/26.

Guha, R. (1997). Not at home in empire. Front Lines/Border Posts, Special Issue of Critical Inquiry 23, no. 3 (Spring): 482-493. https://doi.org/10.2307/1344031.

Hall, A. (1751). Hall to Margaret Hall, 17 December. Letter. National Archives of Scotland, Edinburgh. GD206/500/2.

Hall, A. (1756). Hall to John Hall, 24 February. Letter. National Archives of Scotland, Edinburgh. GD206/499/17.

Hall, A. (1762). Hall to John Hall, 17 April. Letter. National Archives of Scotland, Edinburgh. GD206/2/499/19.

Hall, A. (1763). Hall to John Hall, 3 September. Letter. National Archives of Scotland, Edinburgh. GD206/499/4.

Hancock, D. (2007). Combining success and failure: Scottish networks in the Atlantic wine trade. In D. Dickson, J. Parmentier \& J. Ohlmeyer (Eds.), Irish and Scottish Mercantile Networks in Europe and Overseas in the Seventeenth and Eighteenth Centuries (pp. 5-38). Gent: Academia Press.

Londonderry Corporation. (1699). Council Meeting, 26 September. Manuscript. Londonderry Corporation Minute Book. P.R.O.N.I., Belfast. MIC440/1: f. 174.

Londonderry Corporation. (1700)a. Council Meeting, 2 January. Manuscript. Londonderry Corporation Minute Book. P.R.O.N.I., Belfast. MIC440/1, f. 178.

Londonderry Corporation. (1700)b. Council Meeting, 2 April. Manuscript. Londonderry Corporation Minute Book. P.R.O.N.I., Belfast. MIC440/1, f. 184.

MacKillop, A. (2006). Europeans, Britons and Scots: Scottish sojourning networks and identities in India, c.1700-1815. In A. McCarthy (Ed.) A global clan: Scottish migrant networks and identities since the eighteenth century, (pp. 19-47). London: Tauris Academic Studies.

MacKillop, A. (2008). A union for empire? Scotland, the English East India Company and the British Union. Scottish Historical Review 87, no. 2: 116-134.

Mentz, Søren. (2005). The English gentleman merchant at work: Madras and the city of London, 1660-1740. Copenhagen: Museum Tusculanum Press.

Sen, I. (2005). The Memsahib's 'Madness': The European woman's mental health in late nineteenth-century India. Social Scientist 33, no. 5/6 (May-June): 26-30.

Teggin, E. O. (2020). The East India Company career of Sir Robert Cowan in Bombay and the western Indian Ocean, c. 1719-35. (Doctoral dissertation, School of Histories and Humanities, Trinity College).

Walsh, P. (2010). The making of the Irish protestant ascendancy: The life of William Conolly, 1662-1729. Woodbridge: Boydell Press.

Walsh, P. (2014). The South Sea bubble and Ireland: Money, banking and investment, 16901721. Woodbridge: Boydell Press.

Wilson, J. E. (2010). The domination of strangers. 2nd ed. Basingstoke: Palgrave Macmillan. 